\title{
First confirmed record of Sparid Pagellus bogaraveo (Brünnich, 1768) in the Syrian marine waters (Levantine Basin)
}

\author{
Adib Saad ${ }^{1 *}$, Mai Masri ${ }^{1}$ and Waad Sabour ${ }^{2}$
}

\begin{abstract}
This paper aims to present the first record of Pagellus bogaraveo (Brünnich, 1768) from Syria marine waters. One specimen was caught by trawl nets at about 300 m depth in Rass Albassit, north of Lattakia, on 25 February 2019, and 6 additional specimens were caught by gill nets at a depth of $120 \mathrm{~m}$ off Jablah coast on 7 April 2019. This record represents the first sighting of this immigrant Atlantic species introduced in the Eastern Mediterranean (Levantine Basin). These specimens were found mixing in the same net haul with populations other Sparidae species such as: Pagellus acarne and Dentex macrophthalmus.
\end{abstract}

Keywords: Sparidae, Pagellus bogaraveo, First record, Syrian marine waters, Levantine Basin

\section{Background}

The Mediterranean is considered as a semi-enclosed sea; the Western and Eastern basins are separated by siculoTunisian strait. The narrow Gibraltar strait is the only sill connection with the Atlantic Ocean. Due to strong evaporation in the Eastern Basin, there is a constant flow of near-surface waters that enter through Gibraltar from the Atlantic into the Mediterranean and running eastward along the North African coast. When reaching the Levantine Basin, this general Atlantic current directs northward along Syro-Lebanese coast and in a westerly direction via southern Turkey, Greece and back to Western Mediterranean until Gibraltar. (Lakkis 2002, 2013; Papaconstantinou 2014).

The Sparidae family includes 148 species worldwide belonging to 37 genus (Nelson et al. 2016). From this high species diversity, 28 species are found in Syrian waters, from which one Crenidens crenidens (Forsskal, 1775) is an immigrant species from the Red Sea (Saad 2005), and another species, Pagellus bellottii (Steindcner, 1882) originates in the Eastern Atlantic and the Western Mediterranean (Sbaihi and Saad 1992; Fricke et al. 2014). The genus Pagellus is represented in Syrian marine waters

\footnotetext{
* Correspondence: adibsaad52@gmail.com

${ }^{1}$ Marine Sciences Laboratory, Faculty of Agriculture, Tishreen University, Lattakia, Syria

Full list of author information is available at the end of the article
}

by three congeneric species: Pagellus acarne (Risso, 1826), P. erythrinus (Linneans, 1758) and P. bellottii (Steindcner, 1882) (Saad 2005; Ali 2018).

The Blackspot seabream P. bogaraveo (Brünnich, 1768), Sparidae, is a demersal fish, inhabiting the Eastern Atlantic Ocean, extending in the East Atlantic from Mauritania to Norway. It is found in regions of Mauritania (Cape Blanco), Morocco, Madeira, Canary and Azores Islands, Gibraltar strait and northward up to North Atlantic. It is common in the Western Mediterranean; becomes rare east of Sicily, the southern Adriatic, Aegean Sea, Sea of Marmara, and is absent from the Black Sea (Krug 1990; Bauchot and Hureau 1986; Spedicato et al. 2002; Mytilineou et al. 2005; Chilari et al. 2006; Wirtz et al. 2008; Herrera 2012). It has recently been recorded in the south-eastern Mediterranean Sea, Port Said, Egypt (Stamouli et al. 2017). The larvae are planktonic and juveniles occur in coastal waters. The adults can be found above rocky, sandy and muddy bottoms from inshore water, down to $400 \mathrm{~m}$ in deep water in the Mediterranean and $700 \mathrm{~m}$ in the Atlantic (Bauchot and Hureau 1986). Adult individuals are found on offshore seamounts in Azorean waters (Pinho et al. 2014).

The species has not been reported before in the Levantine Basin (Saad 2005; Keskin et al. 2011; Carpenter and Russell 2014). We present here the first confirmed occurrence of $P$. bogaraveo from Syrian waters, and also from the wider Levantine Basin. The main meristic parameters of the seven individuals observed are provided." 


\section{Material and methods}

One specimen of $P$. bogaraveo was caught on 25 February 2019 , with a surface seawater temperature of $17^{\circ} \mathrm{C}$ and salinity $39.15 \%$, fish were caught during commercial fishing operation, at a depth of 150-300 m, over sandy-rocky bottom, off the shore of Rass $\mathrm{Al}$ Bassit, a locality $60 \mathrm{~km}$ north of Lattakia $\left(35^{\circ} 50^{\prime} \mathrm{N}, 35^{\circ} 50^{\prime} \mathrm{E}\right)$. Six other specimens were caught on 7 April 2019, with seawater $\mathrm{T}^{\circ}=19^{\circ} \mathrm{C}$ and $\mathrm{S}=39.20 \%$ at $4 \mathrm{~km}$ north of Jablah City $\left(35^{\circ} 21^{\prime} \mathrm{N}, 35^{\circ}\right.$ $48^{\prime} \mathrm{E}$ ), using gill net, at a depth of approximately $120 \mathrm{~m}$, on sandy-rocky bottom (Fig. 1).

According to the data given in Table 1, the seven specimens were measured to the nearest $(\mathrm{mm})$, weighted to the nearest (gram) and morphometric measurements with percentages of standard length (SL). All analyzed specimens were preserved in $10 \%$ buffered formalin and deposited in the Collection of the laboratory (Figs. 2 and 3).

\section{Result}

$P$. bogaraveo specimens (Figs. 2 and 3) have a total length (TL) between $110 \mathrm{~mm}$ and $194 \mathrm{~mm}$, with total weight (TW) between $18.95 \mathrm{~g}$ and $74.61 \mathrm{~g}$. Morphometric and meristic data of the seven specimens are summarized in (Table 1). The specimens of this species present the following characteristics: body oblong, upper profile of head curved, snout short; eye diameter greater than snout length; scales on top of head reaching to a line between posterior margin and middle of eyes; cheeks scaly, preopercular scaleless; mouth low, nearly horizontal; in both jaws, a band of conical and slender teeth in front and at least 2 rows of molars at back; the outer series of conical teeth little enlarged and the inner (second) row of molars the largest (Fig. 4). Dorsal fin with 12 spines and 11 to 12 soft rays; anal fin with 3 spines and 11 or 12 soft rays; last dorsal and anal-fin rays stronger than the preceding ones. The number of scales along lateral line is (72 to 74). The colour is more or less reddish grey, darker on head, lighter on belly; a dark spot at pectoral-fin axils and a large black blotch at origin of lateral line (absent in young); fins more or less bright pink; inside of mouth orange red.

$P$. bogaraveo has already been mentioned in the Eastern Mediterranean by Carpenter and Russell (2014), but our survey represents the first record in Syrian marine waters. It is probably an immigrant species from Western Mediterranean into Levantine Basin. The observed specimens were found mixing within populations

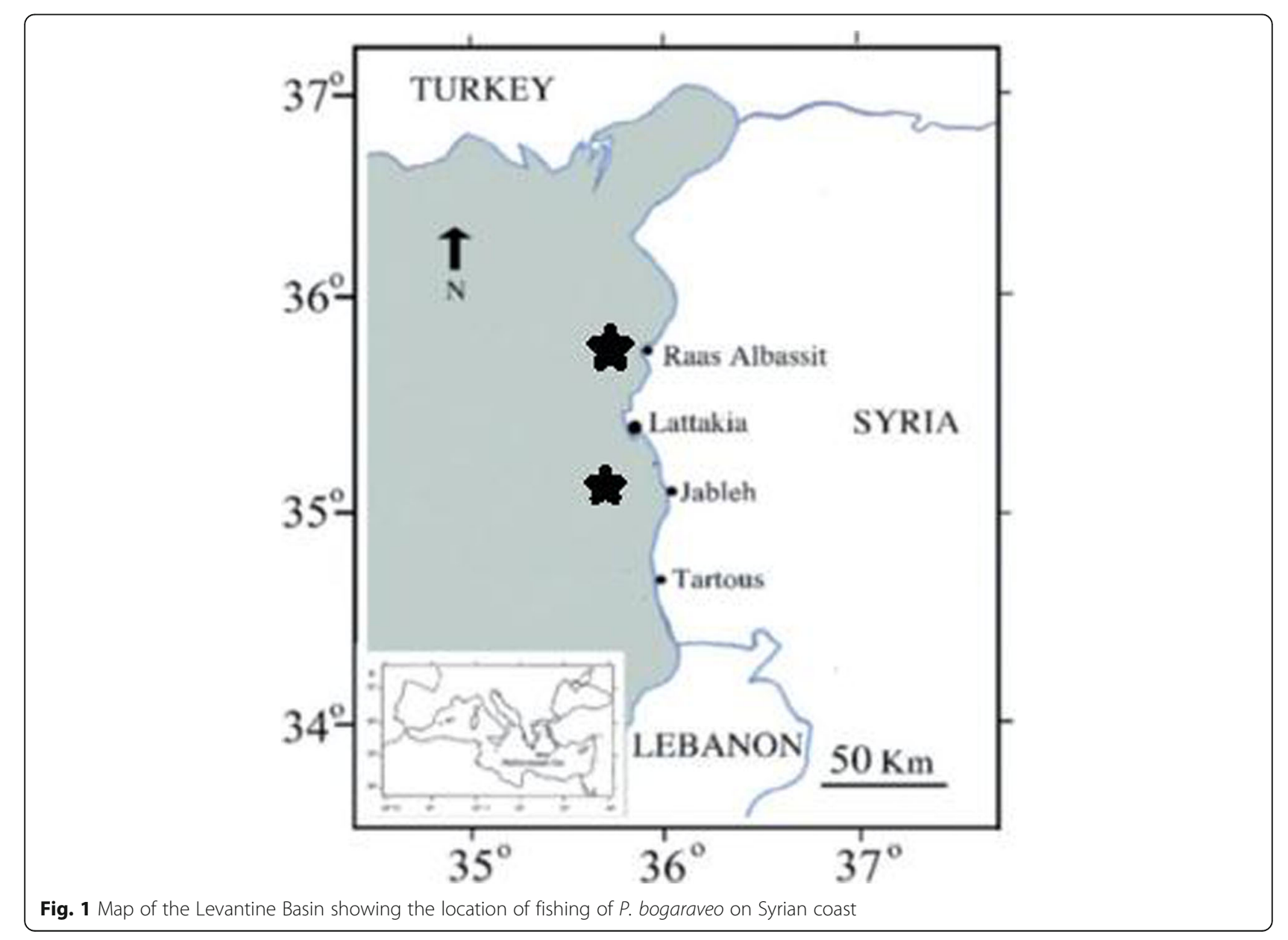


Table 1 Morphometric measurements in $\mathrm{mm}$ and as a percentage of standard length (\%SL), and weight in grams recorded in the 7 specimens of $P$. bogaraveo caught off the Syrian coast

\begin{tabular}{|c|c|c|c|c|c|c|c|c|c|c|c|c|c|c|}
\hline \multirow{2}{*}{$\begin{array}{l}\text { Number of specimens } \\
\text { Morphometric measurements }\end{array}$} & \multicolumn{2}{|l|}{1} & \multicolumn{2}{|l|}{2} & \multicolumn{2}{|l|}{3} & \multicolumn{2}{|l|}{4} & \multicolumn{2}{|l|}{5} & \multicolumn{2}{|l|}{6} & \multicolumn{2}{|l|}{7} \\
\hline & $\mathrm{mm}$ & SL\% & $\mathrm{mm}$ & SL\% & $\mathrm{mm}$ & SL\% & $\mathrm{mm}$ & SL\% & $\mathrm{mm}$ & SL\% & $\mathrm{mm}$ & SL\% & $\mathrm{mm}$ & SL\% \\
\hline Total length (TL) & 194 & $132 \%$ & 128 & $121.90 \%$ & 119 & $121.42 \%$ & 138 & $123.21 \%$ & 121 & $122.23 \%$ & 117 & $121.87 \%$ & 110 & $125 \%$ \\
\hline Standard length (SL) & 150 & $100 \%$ & 105 & $100 \%$ & 98 & $100 \%$ & 112 & $100 \%$ & 99 & $100 \%$ & 96 & $100 \%$ & 88 & $100 \%$ \\
\hline Body depth (BD) & 60 & $40 \%$ & 40 & $38.09 \%$ & 37 & $37.75 \%$ & 42 & $37.50 \%$ & 40 & $40.40 \%$ & 36 & $37.50 \%$ & 34 & $38.63 \%$ \\
\hline Head length (HL) & 47 & $31.30 \%$ & 33 & $31.42 \%$ & 31 & $31.63 \%$ & 36 & $32.14 \%$ & 32 & $32.33 \%$ & 30 & $31.25 \%$ & 29 & $32.95 \%$ \\
\hline Eye diameter (ED) & 21 & $14 \%$ & 12 & $11.42 \%$ & 11 & $11.22 \%$ & 13 & $11.60 \%$ & 11 & $11.11 \%$ & 11 & $11.45 \%$ & 11 & $12.50 \%$ \\
\hline Preorbital length (Pol) & 13 & $8.67 \%$ & 10 & $9.52 \%$ & 9 & $9.18 \%$ & 12 & $10.71 \%$ & 9 & $9.09 \%$ & 9 & $9.37 \%$ & 8 & $9.09 \%$ \\
\hline Predorasal length (Pdl) & 53 & $35.34 \%$ & 38 & $36.19 \%$ & 33 & $33.67 \%$ & 40 & $35.71 \%$ & 36 & $36.36 \%$ & 36 & $37.50 \%$ & 33 & $37.50 \%$ \\
\hline Dorsal fin Base length (D.B.L) & 83 & $55.34 \%$ & 55 & $52.38 \%$ & 51 & $52.04 \%$ & 60 & $53.57 \%$ & 51 & $51.51 \%$ & 50 & $52.08 \%$ & 47 & $53.40 \%$ \\
\hline Anal fin Base length (A.B.L) & 34 & $22.67 \%$ & 26 & $24.76 \%$ & 22 & $22.44 \%$ & 26 & $23.21 \%$ & 24 & $24.24 \%$ & 24 & $25 \%$ & 20 & $22.72 \%$ \\
\hline Prepectoral length (Ppl) & 51 & $34 \%$ & 36 & $34.28 \%$ & 32 & $32.65 \%$ & 38 & $33.92 \%$ & 33 & $33.33 \%$ & 32 & $33.33 \%$ & 29 & $32.95 \%$ \\
\hline Preanal length (Pal) & 101 & $67.34 \%$ & 65 & $61.90 \%$ & 61 & $62.24 \%$ & 70 & $62.50 \%$ & 62 & $62.62 \%$ & 61 & $63.54 \%$ & 57 & $64.77 \%$ \\
\hline \multicolumn{15}{|l|}{ Counts } \\
\hline Scales on lateral line & \multicolumn{2}{|l|}{72} & \multicolumn{2}{|l|}{72} & \multicolumn{2}{|l|}{72} & \multicolumn{2}{|l|}{72} & \multicolumn{2}{|l|}{74} & \multicolumn{2}{|l|}{72} & \multicolumn{2}{|l|}{72} \\
\hline Dorsal fin rays & \multicolumn{2}{|c|}{$X I I+11$} & \multicolumn{2}{|c|}{$X \| 12$} & \multicolumn{2}{|c|}{$X \| 11+11$} & \multicolumn{2}{|c|}{$X \| 11+12$} & \multicolumn{2}{|c|}{$X \|+12$} & \multicolumn{2}{|c|}{$X \|+11$} & \multicolumn{2}{|c|}{$X I I+12$} \\
\hline Anal fin rays & \multicolumn{2}{|c|}{$\| I I+11$} & \multicolumn{2}{|c|}{\|\|$+11$} & \multicolumn{2}{|c|}{|| $\mid+12$} & \multicolumn{2}{|c|}{$\| I \mid+12$} & \multicolumn{2}{|c|}{$\|||+12$} & \multicolumn{2}{|c|}{|| $\mid+12$} & \multicolumn{2}{|c|}{$\|||+12$} \\
\hline Pelvic fin rays & \multicolumn{2}{|l|}{$1+5$} & \multicolumn{2}{|l|}{$1+5$} & $1+5$ & & $1+5$ & & $1+5$ & & $1+5$ & & $1+5$ & \\
\hline Total weight (g) & 74.61 & & 32.17 & & 25.62 & & 39.37 & & 27.65 & & 24.64 & & 18.95 & \\
\hline
\end{tabular}

of two other sparids Pagellus acarne and Dentex macrophthalmus at the depths between $(100-300 \mathrm{~m})$. So that it is evidence that the species has started to establish population in Syrian marine waters.

\section{Discussion}

All measurements, counts, and colour patterns determined the morphological analyses in previous other records of this species in north- eastern Atlantic, the Mediterranean (Whitehead et al. 1986), the Central Eastern Atlantic
(Carpenter and De Angelis 2016) and the south-eastern Mediterranean (Stamouli et al. 2017).

$P$. bogaraveo is widely distributed in the Eastern Atlantic and is known from southern Norway and around the British Isles down to the Western Sahara, including the archipelagos of Madeira (Wirtz et al. 2008), Azores and the Canary Islands (Pinho et al. 2014). It is common in the western Mediterranean, becomes rare east of Sicily (Carpenter and Russell 2014), except for parts of the Adriatic (D'Onghia et al. 2014), the Aegean

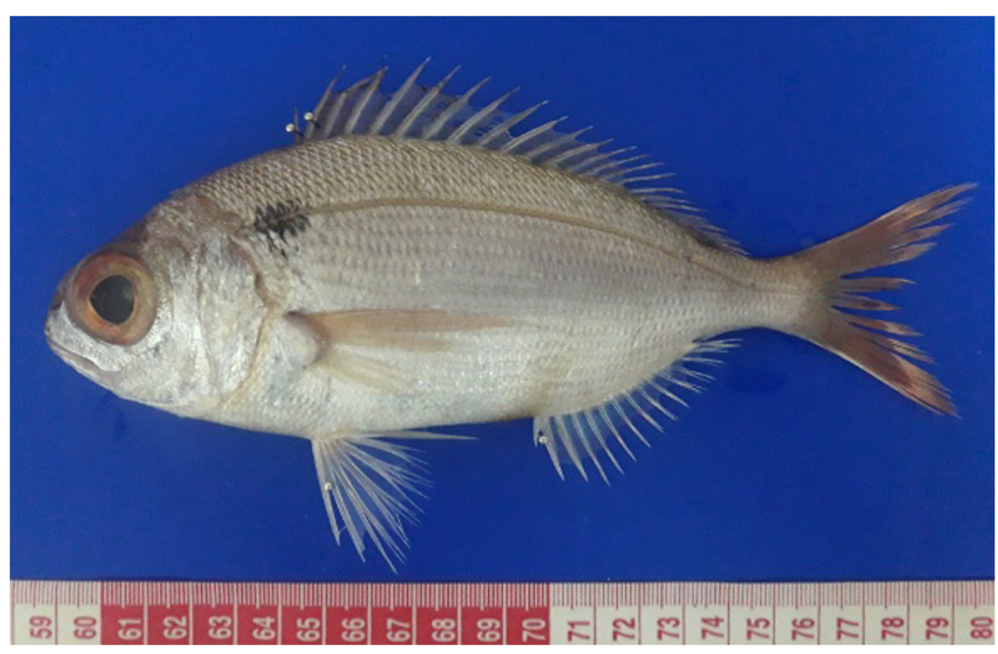

Fig. 2 The first specimen of $P$. bogaraveofrom Lattakia coast 


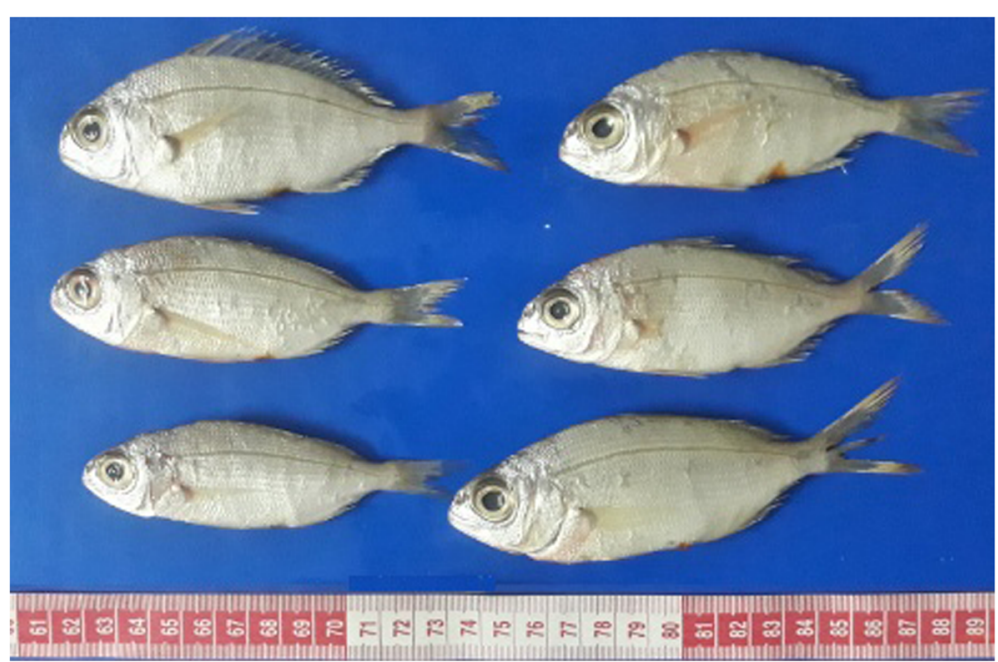

Fig. 3 The 6 other specimens of $P$. bogaraveo from Jablah coast

and the Sea of Marmara (Akyol and Ertosluk 2010; Keskin et al. 2011; Bilecenoğlu et al. 2014). It is absent from the eastern to southeastern Mediterranean Sea and the Black Sea (Bauchot and Hureau 1986; Carpenter and Russell 2014).

This species may have been presented in Syrian marine waters as a companion of $P$. bellottii but it has not been confirmed by researchers (Sbaihi and Saad 1992; Saad and Sbaihi 1995; Saad 2005; Ali 2018).

There may have been misidentification issues with $P$. bogaraveo which complicates assessing its spread in the Mediterranean Sea (Table 2). It is difficult to distinguish Pagellus bellottii from Pagellus erythrinus. They can be confused in terms of general appearance, but they differ from each other by their length of anal-fin base and soft anal-fin rays: whereas the length of anal-fin base shorter than distance from snout tip to posterior margin of eye and (8-9) soft anal-fin rays in P. erythrinus (Whitehead et al. 1986; Carpenter and De Angelis 2016; Jawad et al.
2017), while the length of anal-fin base greater than distance from snout tip to posterior margin of eye and (10) soft anal-fin rays in P. bellottii (Whitehead et al. 1986; Carpenter and De Angelis 2016; Samuel and Pascal 2016).

On the other hand, P. bogaraveo is similar to Pagellus acarne regarding the scalation on top of head ending behind a transverse line through middle of eyes, and the colour intside of mouth orange-red. However, P.bogaraveo has (11or 12) anal-fin rays, eye diameter greater than length of snout and a dark blotch at origin of lateral line (Stamouli et al. 2017); whereas P. acarne has (9 or 10) anal-fin rays; eye diameter smaller than, or equal to length of snout and a very dark red blotch at upper level of pectoral fin insertion (Whitehead et al. 1986; Carpenter and De Angelis 2016).

There is a great similarity in the formalities between the Pagellus bellottii and Pagrus pagrus, but it can be easily distingshed by an examination of the anterior teeth in each jaw, there are 4 upper and 6 lower stronger

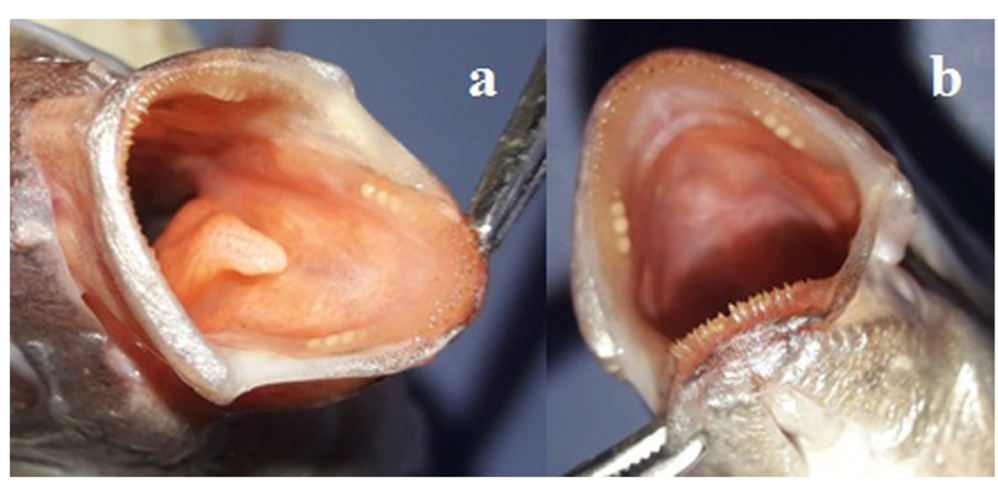

Fig. 4 Teeth of $P$. bogaraveo Specimen from Lattakia coast. a lower jaw; b upper jaw 


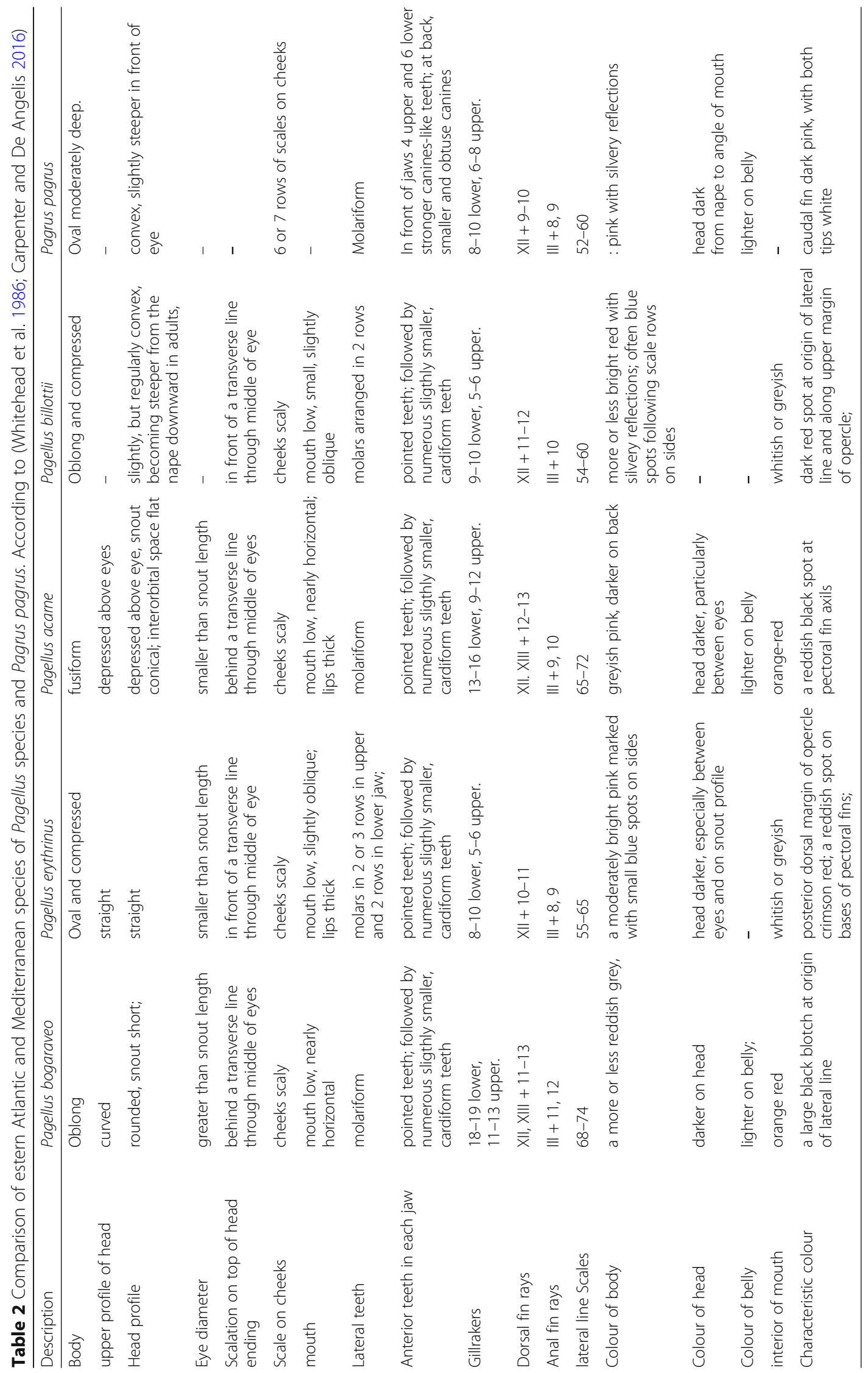


canines-like teeth; at back, smaller and obtuse canines in Pagrus pagrus (Whitehead et al. 1986; Carpenter and De Angelis 2016), and there are pointed teeth; followed by numerous sligthly smaller, cardiform teeth in Pagellus bellottii (Whitehead et al. 1986; Carpenter and De Angelis 2016; Samuel and Pascal 2016).

$P$. bogaraveo is a demersal species that occurs mostly on the continental shelf slope, on rocky, sandy and muddy bottoms (Afonso et al. 2012) and around islands, at depths of up to $800 \mathrm{~m}$ in the Adriatic (Spedicato et al. 2002). It has been observed at a depth of $787 \mathrm{~m}$ at Bari Canyon (Southern Adriatic Sea) in groups of up to 40 individuals D'Onghia et al. 2014). The young individuals are found near to the shore, whereas the adults on the continental slope, especially over muddy bottoms. In the eastern Ionian Sea, the species inhabits the shallow waters of the shelf $(170 \mathrm{~m}$ depth) as juveniles of $180 \mathrm{~mm}$ LT, moving to deeper waters of the slope (mainly 400$500 \mathrm{~m}$ depth) as adults (Mytilineou et al. 2013).

\section{Conclusion}

Seven specimens of $P$. bogaraveo were captured from Syrian coastal waters, mixed with populations of Pagellus acarne and Dentex macrophthalmus. Previously this species is reported as a native in Atlantic, western and north-eastern Mediterranean. The record in Syrian waters represents the first report of this species in the Levantine Basin. We suppose that is an immigrant from western Mediterranean, the number of specimens is evidence that the species has started to establish a population in Syrian marine waters and extending probably to the entire east Levantine Basin.

\section{Abbreviations \\ E: East; N: North; S: Salinity; SL: Standard length; T: Temperature; TL: Total lengthf}

\section{Acknowledgements}

The authors would like to thank Professor Sami Lakkis for his kindly review of the draft of manuscript.

\section{Authors' contributions}

MM, AS and WS examined specimens and drafted the manuscript. All authors gave the final approval for publication.

\section{Funding}

Not applicable.

\section{Availability of data and materials}

The specimens are available at Marine Science Laboratory-Tishreen university-Lattakia-.

Syria.

\section{Ethics approval and consent to participate}

No ethical approval or consent to participate was required.

\section{Consent for publication}

Not applicable.

\section{Competing interests}

The authors declare that they have no competing interests.

\section{Author details}

'Marine Sciences Laboratory, Faculty of Agriculture, Tishreen University, Lattakia, Syria. ${ }^{2}$ Department of Animal Biology, Faculty of Science, Tishreen University, Lattakia, Syria.

Received: 27 May 2019 Accepted: 13 January 2020

Published online: 23 January 2020

\section{References}

Afonso P, Graca G, Berke G, Fontes J. First observations on seamount habitat use of blackspot seabream (Pagellus bogaraveo) using acoustic telemetry. J Exp Mar Biol Ecol. 2012;436-437:1-10.

Akyol O, Ertosluk O. Fishing near sea-cage farms along the coast of the Turkish Aegean Sea. J Appl Ichthyol. 2010;26:11-5.

Ali M. An updated checklist of the marine fishes from Syria with emphasis on alien species. Mediterr Mar Sci. 2018;19(2):388-93.

Bauchot ML, Hureau JC. Sparidae. In: Whitehead PJP, et al., editors. Fishes of the North-Eastern Atlantic and the Mediterranean. Paris: UNESCO; 1986. p. 516-1007.

Bilecenoğlu M, Kaya M, Cihangir B, Çiçek E. An updated checklist of the marine fishes of Turkey. Turk J Zool. 2014;38:901-29.

Carpenter KE, De Angelis N. The living marine resources of the Eastern Central Atlantic. Volume 4: Bony fishes part 2 (Perciformes to Tetradontiformes) and Sea turtles. Rome: FAO Species Identification Guide for Fishery Purposes; 2016. FAO. p. 2343-3124.

Carpenter, K.E. \& Russell, B. Pagellus bogaraveo. The IUCN Red List of Threatened Species: e.T170244A1300216. (2014). http://dx.doi.org/10.2305/IUCN.UK.2014 3.RLTS.T170244A1300216.en.

Chilari A, Petrakis G, Tsamis E. Aspects of the biology of blackspot seabream (Pagellus bogaraveo) in the Ionian Sea, Greece. Fish Res. 2006;77:84-91.

D'Onghia G, Capezzuto F, Carluccio A, Carlucci R, Giove A, Mastrototaro F, Panza M, Sion L, Tursi A, Maiorano P. Exploring composition and behaviour of fish fauna by in situ observations in the Bari canyon (southern Adriatic Sea, Central Mediterranean). Mar Ecol. 2014;36(3):541-556.

Fricke R, Golani D, Sonin O, Appelbum - Golani B. First record of Red Pandora Pagellus bellottii from south - eastern Mediterranean (Teleostei: Sparidae). Marine Biodiversity. 2014;7:E130. https://doi.org/10.1017/s175526214001316.

Herrera, J.G. Updated information from the Spanish Blackspot seabream (Pagellus bogaraveo) fishery in the Strait of Gibraltar area. Working document presented to the second meeting of the FAO CopeMed II Working Group on Blackspot Seabream (Pagellus bogaraveo) of the Strait of Gibraltar area between Spain and Morocco, WGPG - Tangiers (Morocco), 2012. FAO occasional paper 10.

Jawad LA, Akyol O, Aydin I. First Records of Saddleback Syndrome and Pughead Deformities in the Common Pandora Pagellus erythrinus (Linnaeus, 1758) (Teleostei: Sparidae) from Wild Population in the Northern Aegean Sea, Turkey. Int J Mar Sci. 2017;7(19). https://doi.org/10.5376/ijms.2017.07.0019.

Keskin Ç, Turan C, Ergüden D. Distribution of the Demersal fishes on the continental shelves of the Levantine and North Aegean seas (eastern Mediterranean). Turk J Fish Aquat Sci. 2011;11:413-23.

Krug H. M. the Azorean blackspot seabream, Pagellus bogaraveo (Bruennich 1768) (Teleostei, Sparidae). Reproductive cycle, hermaphroditism, maturity and fecundity. Cybium. 1990;14:151-9.

Lakkis S. Archiving and Rescue of oceanographic data in Eastern Mediterranean, vol. 4. France: MEDAR/MEDATLAS II EC Project, IFREMER; 2002. CD Rom

Lakkis S. Flore et Faune marines du Liban et de la Méditerranée Orientale: Biologie, Biodiversité, Biogéographie, Aracne Editrice, ISBN 978-88-548-63354, Rome, Italie, vol. 512; 2013.

Mytilineou C, Politou C-Y, Papaconstantinou C, Kavadas S, D'Onghia G, Sion L. Deep water fish fauna in the eastern Ionian Sea. Belgian J Zoology. 2005; 135(2):229-33.

Mytilineou C, Tsagarakis K, Bekas P, Anastasopoulou A, Kavadas S, Machias A, Haralabous J, Smith CJ, Petrakis G, Dokos J, Kapandagakis A. Spatial distribution and life-history aspects of blackspot seabream Pagellus bogaraveo (Osteichthyes: Sparidae). J Fish Biol. 2013;83:1551-75.

Nelson JS, Grande TC, Wilson MVH. Fishes of the world. 5th ed. United States of America: Wiley; 2016. p. 707.

Papaconstantinou C. Fauna Graeciae. An updated checklist of the fishes in the Hellenic seas. Monagraphs Mar Sci. 2014;7:340.

Pinho M, Diogo H, Carvalho J, Gil Pereira J. Harvesting juveniles of blackspot sea bream (Pagellus bogaraveo) in the Azores (Northeast Atlantic): biological 
implications, management, and life cycle considerations. ICES J Mar Sci. 2014; 71(9):2448-56. https://doi.org/10.1093/icesjms/fsu089.

Saad A. Check-list of bony fish collected from the coast of Syria. Turkish J Fish Aquatic Sci. 2005:5:99-106.

Saad A, Sbaihi M. Mise en evidence de la prde la pra prde la prr la pred from the coast of Syria. ia. ement, and life cycle considerations. ICES J Mar Sci. 1995;34: 256 Acte de la 34a $p$ congrès de la CIESM.

Samuel PI, Pascal L. First record of Pagellus bellottii (Teleostei: Sparidae) in the Bay of Biscay, France. Mar Biodiversity Records. 2016;9:16. https://doi.org/10.1186/ s41200-016-0007-8.

Sbaihi M, Saad A. Données nouvelles sure des espèces de poissons téleostéens pêchées pour la première fois dans les eaux terretoriales Syriennes. Acte des travaux de la semaine de science Damas. 1992;3:83-105 (in arabic with abstract in french).

Spedicato MT, Greco S, Sophronidis K, Lembo G, Giordano D, Argyri A.

Geographical distribution, abundance and some population characteristics of the species of the genus Pagellus in different areas of the Mediterranean. Sci Mar. 2002;66(S2):65-82.

Stamouli C, Akel EH, Azzurro E, Bakiu R, Bas AA, Bitar G, Boyaci YÖ, Cakalli M, Corsini-Foka M, Crocetta F, Dragičević B, Dulčić J, Durucan F, Zrelli RE, Erguden D, Filiz H, Giardina F, Giovos I, Gönülal O, Hemida F, Kassar A, Kondylatos G, Macali A, Mancini E, Ovalis P, Paladini De Mendoza F, Pavičić M, Rabaoui L, Rizkalla SI, Tiralongo F, Turan C, Vrdoljak D, Yapici S, Zenetos A. New Mediterranean biodiversity records (December 2017). Mediterr Mar Sci. 2017;18(3):534-1.

Whitehead PJP, Bauchot ML, Hureau JC, Nielsen J, Tortonese E. Fishes of the North- eastern Atlantic and the Mediterranean. Vol. 2. Paris: Ed. Unesco; 1986. pp 517-1007.

Wirtz P, Fricke R, Biscoito MJ. The coastal fishes of Madeira Island—new records and an annotated check-list. Zootaxa. 2008;1715(1):1-26.

\section{Publisher's Note}

Springer Nature remains neutral with regard to jurisdictional claims in published maps and institutional affiliations.

Ready to submit your research? Choose BMC and benefit from:

- fast, convenient online submission

- thorough peer review by experienced researchers in your field

- rapid publication on acceptance

- support for research data, including large and complex data types

- gold Open Access which fosters wider collaboration and increased citations

- maximum visibility for your research: over $100 \mathrm{M}$ website views per year

At $\mathrm{BMC}$, research is always in progress.

Learn more biomedcentral.com/submissions 